\title{
Windt Szandra
}

\section{Az emberkereskedelem és a családon belüli erőszak hasonlóságai és különbségei}

\author{
Similarities and differences between human trafficking \\ and domestic violence
}

\begin{abstract}
Absztrakt
Az emberkereskedelem komplex jelenségét, összetettségét különböző módon igyekszik a szakirodalom megragadni. Az alábbiakban egy olyan aspektusára hívnánk fel a figyelmet, amely a segító szervezetek számára ismert, ám tudományos cikkekben kevés szó esett róla. A kiszolgáltatott helyzetben lévő sértett szexuális munka vagy egyéb célú kizsákmányolásának megelőzése, annak felderítése, bizonyítása és büntetése nagy feladatot ró a nyomozó hatóság és a büntető igazságszolgáltatás szereplöire. Az ilyen tárgyú eljárások száma sajnálatosan alacsony, amely részben a sértettek szégyenérzetéből fakad(hat), az elkövetővel szembeni függőségi viszonyuk az, amely miatt nem fordulnak a hatósághoz, illetve a vallomásaik sokszor ellentmondásosak, nem egyértelmüek. A 2011/36. EU irányelv alapján az ezen büncselekmény tárgyában indult büntetőeljárást lehetőség szerint nem csak a sértett vallomására kell felépíteni. A családon belüli erőszak dinamikájához hasonló folyamatok zajlanak sokszor az emberkereskedelem esetében is. Az alábbiakban a két jelenség hasonlóságait és különbségeit gyüjtöttük egybe az emberkereskedelem jelenségének bemutatását követően, remélve, hogy ez segítséget nyújthat az emberkereskedelem ellen történő fellépés hatékonyabbá tételéhez.
\end{abstract}

Kulcsszavak: emberkereskedelem, családon belüli erőszak, Magyarország, áldozat

\begin{abstract}
The literature tries to capture the compound phenomenon and complexity of human trafficking in different ways. We would like to highlight an aspect which
\end{abstract}


is known for help organizations, but which has seldom been mentioned in scientific articles. Preventing, detecting, proving, and punishing the exploitation of a vulnerable victim for sexual, labour or other purposes is a major task for investigative authorities and the judiciary. Unfortunately, the number of proceedings in this area is low, due in part to the victims' feelings of shame, their dependency on the perpetrator are the main reasons why they do not turn to the authorities, and their testimonies are often contradictory and unclear. Pursuant to the EU Directive 2011/36, criminal proceedings in respect of this offense should, as far as possible, not be based solely on the testimony of the victim. Processes similar to the dynamics of domestic violence often occur in the case of trafficking human beings. The similarities and differences can be read between the two phenomena, following the introduction of the phenomenon of trafficking human beings, in the hope that this might help to make the fight against trafficking more effective.

Keywords: trafficking human beings, domestic violence, Hungary, victim

\section{Bevezetés}

„Folyamatosan a felügyelete alatt voltam, azt mondta, hogy azért, mert tartozom neki, nem vállalhatok másik munkát, csak, amit ö mond, azt csináljam, én bolond vagyok, ne gondolkozzak." (Eset1) - mondta vallomásában egy kényszermunka-büncselekmény sértettje. Ismerősek ezek a szavak, amelyek oly jól ismertek a családon belüli erőszak eseteiben? A pszichikai hatás, az elnyomás, a másik folyamatos megalázása ebben a vallomásban is tetten érhető (Hercsel, 2018). Az emberkereskedelem komplex jelenségét, összetettségét különböző módon igyekszik a szakirodalom megragadni. Az alábbiakban egy olyan aspektusra hívnánk fel a figyelmet, amely a segítő szervezetek számára ismert, ám tudományos cikkekben még kevés szó esett róla (Segrave et al., 2020). A kiszolgáltatott helyzetben lévő sértett szexuális, munka vagy egyéb célú kizsákmányolásának megelőzése, annak felderítése, bizonyítása és büntetése nagy feladatot ró a nyomozó hatóság és az igazságszolgáltatás szereplöire. Az ilyen tárgyú eljárások száma sajnálatosan alacsony, amely részben a sértettek szégyenérzetéből fakad(hat), az elkövetővel szembeni függőségi viszonyuk az, amely miatt nem fordulnak a hatósághoz, illetve a vallomásaik sokszor ellentmondásosak, nem egyértelmüek. A 2011/36 EU irányelv 9. cikk (1) alapján az ezen büncselekmény tárgyában indult büntetőeljárást lehetőség szerint nem csak a sértett vallomására kell felépíteni. „A tagállamok biztositják, hogy a 2. 
és 3. cikkben emlitett büncselekmények ügyében folytatott nyomozásra és büntetöeljárásra a sértett bejelentésétől vagy vádemelésétöl függetlenül sor kerüljön, továbbá hogy az eljárás abban az esetben is folytatódhasson, ha a sértett visszavonta a vallomását."1

Ebben a tanulmányban az Országos Kriminológiai Intézetben 2019-ben zajlott kutatás ${ }^{2}$ során szerzett egyik igen fontos eredményt gondoljuk tovább, az emberkereskedelem és a családon belüli erőszak ${ }^{3}$ jelensége közötti párhuzamot: hasonlóságok felvázolása mellett kiemelve a markáns különbségeket is. Azzal a céllal, hogy rámutassunk azokra a személyközi dinamikákra, amelyek mindkét esetben megjelennek, remélve, hogy ezzel az esetek feltárása, az azok elleni fellépés még eredményesebb lesz.

\section{Az emberkereskedelem jelensége}

Emberkereskedelem, modern rabszolgaság, szexmunkás, kizsákmányolás, csicskák, házi rabszolgák - az utóbbi években ezek a kifejezések a leginkább közismertek az emberkereskedelemmel kapcsolatban a sajtóban, hiszen ez egy népszerü, közkedvelt téma, ugyanakkor a kifejezések sokszor félreérthetők, bántók a sértettekre nézve, és további kutatások tárgyát képezhetik. A 2017-ben publikált Az emberiség tragédiája: modernkori rabszolgaság címü kötetben az egyes, gyakran használt kifejezések közötti különbség olvasható: „A modern rabszolgaság fogalmánál jóval ismertebb fogalom az emberkereskedelem és gyakorta a két fogalmat szinonimaként használják. Habár a két jelenség között jelentös átfedés van, hiszen a modernkori rabszolgaságban élök nagy része az emberkereskedelem útján kerül becsapott, kiszolgáltatott, bántalmazott, megalázott, szolgai élethelyzetbe, az emberkereskedelem mégsem azonos a modernkori rabszolgasággal." (Mihalkó et al., 2017, 48.) A szerzők szerint az egyik egy állapot, a másik egy folyamat: az emberkereskedelem emberi jogokat sértő, hatalmas profitot termelő iparág, amelynek végállomása lehet a rabszolgaság állapota (Mihalkó et al., 2017, 49-50.). Az emberkereskedelem 2020-ban már nem csupán az emberpiacon történő adás-vételt jelenti (bár sajnálatosan ez is jelen van még mindig). Az elmúlt húsz évben, ahogy a módszerek változtak, egyre inkább

1 2011/36 EU irányelv 9. cikk (1).

2 Az Országos Kriminológiai Intézetben a 2019-es évben ,Az emberkereskedelmi ügyek sajátosságai, a kizsákmányolás büntetöjogi, kriminológiai és szociológiai értékelése” címmel folytattunk le egy kutatást Deres Petronellával.

3 Kriminológiai értelemben szólunk itt a családon belüli erőszak jelenségéről, a kapcsolati erőszak tényállásáról (Btk. 212/A §) lásd bővebben Garai Renáta tanulmányait. 
az egyszerü, jól megragadható kereskedelmi aktust felváltotta a kizsákmányolás kifejezés. Ma már azt mondjuk, hogy a kereskedelmi aktus mellett az emberkereskedelem a szexuális, munka és úgynevezett egyéb célú (kényszerházasság, kényszerkoldultatás, szervkereskedelem stb.) kizsákmányolást is magában foglalja. A 2018-ban megjelent „Data collection on trafficking in human beings in the EU' (URL1) címủ kiadványban olvashatók az uniós adatok 2015-2016-ra vonatkozóan. Ez alapján a 2015-2016-os években 20.532 regisztrált áldozata volt az emberkereskedelemnek az EU egész területén, míg a büntetőeljárások száma közel 6.000 volt, a büntetőítéleteké 3.000. Az emberkereskedelem jelenségeinek megoszlása 2013-2014-hez képest némi változást mutat. A szexuális kizsákmányolás továbbra is az esetek kb. kétharmadában fordult elő. A munka célú kizsákmányolás azonban némileg csökkent (21-ről 15\%-ra), míg az egyéb célú kizsákmányolások aránya 12\%-ról 20\%-ra emelkedett (Windt, 2019). A szexuális kizsákmányolás áldozatainak száma az uniós országokban 10 ezer főre tehető (2013-14-ben 10.644; 2015-16-ban 9.759 fő volt). Az áldozatok nemek szerinti megoszlása alapján elmondható: az emberkereskedelem áldozata inkább nő, mint férfi, bár arányuk némileg csökkenést mutat a vizsgált években (76\%-ról 68\%-ra). Aggasztó azonban, hogy a gyermekkorú áldozatok aránya növekedést mutat (15\%-ról 23\%-ra), a 2013-14-es években az Európai Unió országaiban 2.375 gyermeket azonosítottak emberkereskedelem áldozataként. A legtöbb kutatás a szexuális célú kizsákmányolás, a prostitúcióra kényszerítés feltárására törekszik (Fehér, 2005, 217.). A munka célú kizsákmányolásról még kevesebb adat áll rendelkezésre, sajnálatosan kevés tanulmány készült ezzel a problémával kapcsolatban annak ellenére, hogy nemzetközi és nemzeti szinten is mutatkoznak egyre aggasztóbb jelek (Doyle et al., 2019). Az idézett uniós adatok szerint emberkereskedelem tekintetében Magyarország sajnálatos módon az öt kibocsátó ország között van. Az emberkereskedelem magyar áldozatai leginkább az ország társadalmi-gazdasági szempontból lemaradó területein, mélyszegénységben élnek, illetve onnan származnak, jól körülhatárolhatók ezek a kibocsátó gócpontok, elég egyértelmü jelzés erre a Nyíregyháza utca Amszterdamban, s az északkeleti megyékben élő (sok esetben roma) nők veszélyeztetettsége a szexuális kizsákmányolás szempontjából különösen jelentős (Solt, 2009, 42-43.). Az emberkereskedelem áldozatává válók szinte mindegyike alacsony iskolai végzettséggel rendelkezik, a kecsegtetőnek tünő ajánlattal a munkanélküliségből, a kilátástalanságból igyekeznek kitörni, sok esetben rosszabb helyzetbe kerülve ezzel (Solt, 2009, 30-56.). A sértettek mentális, fizikai állapotáról is szót kell ejtenünk: a vizsgált büncselekmény megvalósulása során a sértettek olyan mértékủ fizikai és lelki károsodást szenvedtek, amelynek feldolgozása hosszú időt és segítséget igényel. Ez nehezíti a sértett büntetőeljárásban való részvételét, megbízhatóságát. 


\section{Az emberkereskedelem folyamata}

Az emberkereskedelem során az alábbi tevékenységek fordulnak elö, jellemzően egymást követő láncolatban: eladás, vásárlás, elcserélés, átadás, átvétel, toborzás, szállítás, elszállásolás, elrejtés, végül valamilyen tevékenység elvégzésére kényszerítés. Az általunk vizsgált iratokban a toborzás a kapcsolati hálón keresztül (barátnő ismert valakit, ismerősön keresztül, családtagok segítségével stb.) zajlott leginkább, a hirdetésre való jelentkezésre kevés esetben találtunk bizonyítékot (URL2, 53.). A kontrollnak végig fontos szerepe van a toborzás, a szállítás, a szállás biztosítása és a kizsákmányolás során. Ez sok esetben fizikai kényszer, bántalmazás formájában valósult meg, de volt példa a szexuális szolgáltatás végzése során történő videokamerás megfigyelésre, a laptop kamerájának e célból történő felhasználására is. (Ez nyilvánvalóan a kliens személyiségi jogainak megsértésével együtt történt.) A szexuális célú kizsákmányolás, azaz a prostitúciós tevékenységekre történö kényszerítés mögött a mielőbbi, minél magasabb (leginkább anyagi) haszon- és előnyszerzés húzódik. A pénz mozgása, útja sok esetben segítheti a nyomozókat, bár az ékszerekben, aranyakban történő átváltás, a telekocsikban hazaküldött készpénz nyomát sokkal nehezebb követni(URL2, 53.). Voltak sértettek, akiknél felmerült a család negatív szerepe, mivel az áldozattá válásukban ők is szerepet játszottak: apa, aki eladja/áruba bocsátja a lányát; a nagybácsi, aki prostitúciós munkát ajánl; az anya, aki az ebből a helyzetből kilépni kívánó lányát becsmérli. A sértettek kilépését ebből az ördögi körböl ez (is) nehezíti. Különösen annak lehetetlen szinte, akinek nincsenek családi kapcsolatai, akihez fordulhat, és itt nemcsak a gyermekotthonban nevelkedö lányokra, de az özvegy, idős emberekre is gondolunk, akik kényszermunka sértettjeivé váltak. Itt kell utalnunk arra, hogy az emberkereskedelem, így mind a szexuális, mind a munka célú kizsákmányolás a kiszolgáltatott, sanyarú helyzet kihasználására épül, így bár nyilvánvalóan az igazságszolgáltatás szereplöinek is van teendője ennek a jelenségnek megelőzésében, a probléma gyökerét önmagában nem tudja megoldani, ahhoz társadalomés szociálpolitikai lépések megtétele szükséges. Az emberkereskedelem hazai jogalkalmazói gyakorlatából az tűnik ki, hogy a szexuális célú kizsákmányolás inkább a jellemző, a munka célú kevésbé. Éppen emiatt az említett OKRI kutatásba bevontuk a kényszermunkát tartalmazó ügyiratokat is, amelyek a munkacélú kizsákmányolás jellemzőit világosan bemutatta számunkra. A nemzetközi szakirodalom szerint leginkább a szezonálisakat - mezőgazdaság, építkezés, halászat stb. -, azaz a kevéssé szabályozott területeket próbálják az elkövetők kihasználni. Ahol külföldi állampolgárt alkalmaznak, ott sok esetben legális foglalkoztatás és a munkacélú kizsákmányolás közötti szürke zónát igyekeznek 
megteremteni: sokan az eredeti országuk minimálbérét kapják csak, de ilyen a mi vizsgálatunkban csupán egyszer fordult elő. Az általunk vizsgált ügyek alapján elmondható: a kényszermunka sértettjének alkohol problémái vannak, hajléktalan, munkanélküli, rendkívül rossz egészségi állapotban van, alacsony értelmi szintű személy, illetve időskorú. Nemüket tekintve a kényszermunka áldozatai között jelentős számban voltak férfiak. A kényszermunka áldozatai és a sérelmükre megvalósított bűncselekmények még rejtettebbek, még nehezebb feltárni és bizonyítani, mint a szexuális kizsákmányolás esetén. Az albérlőként, befogadott rokonként nyilatkozók a kiérkező rendőröknek nyilván nem tárják fel a valódi helyzetet. Így lehetséges az, hogy ez az állapot akár hosszabb ideig fennáll. Az elkövetők között nők és férfiak egyaránt voltak. Jellemzően már büntetve voltak korábban, és jól kihasználják a sértett elesettségét, rendszeresen - sokszor évekig - eröszakot alkalmazva rajta. A kényszermunka egyik tipikus esete, amikor a ház körüli munka elvégzésére dolgoztatják az elkövetők a sértetteket. Ezen belül jól körülhatárolható volt az, amikor a sértettet az elkövető magához költöztette, illetve, amikor ö költözött a sértetthez. A legnehezebben bizonyítható az a fajta elkövetői mód, amikor az elkövető magához költözteti a sértettet. Ezekben az ügyekben volt a legtöbb feljelentés elutasítás, nyomozás megszüntetés, hiszen nehezen lehet bizonyítani, hogy a segítő szándékon túl más motivációja is van az elkövetőnek. A sértett bankkártyáját, pénzét, iratait elveszik, a bántalmazás, a félelemben tartás folyamatos. Mivel a sértettet az elkövetők otthonában lakik, így sokkal jobban tudják felügyelni öt, segélyét elveszik, különböző munkára kényszerítik. A félelemben tartás mellett szinte sosincs tisztálkodási lehetőség, az étkezés nem vagy alig biztosított, fizetséget a munkáért nem kap a sértett. „Megállapitható, hogy a tanyán dolgozók nem voltak kiszolgáltatott helyzetben, mivel saját döntésük volt (egyes esetekben saját kérésükre történt), hogy munkát végeznek a tanyán, mely munkáért egyéb juttatásokat kaptak, vagy a munkát - rokonság miatt - szivességböl végezték." (Eset2) (Hercsel, 2018.) „A sértett meghallgatásakor elismeri, hogy a segélyét a gyanúsitottaknak adja, hogy a gyanúsitott fia bokszoló és rajta gyakorol, de mivel a gyanúsitott úgyis megtalálja és visszaviszi, nem keres másik munkát, ott még mindig jobb, mint otthon." (Eset3) (Hercsel, 2018.) A feljelentés elutasítás indoka sok esetben az volt, hogy ,a sértett bármikor elmehetett, szabadságában korlátozva nem volt" (Eset4) (Hercsel, 2018), ugyanakkor ezek a sértettek nyilvánvalóan nem nagyon tudtak hová menni. Nem állt rendelkezésükre arról sem információ, hogy elmehetnek-e egyáltalán, illetve, ha igen, akkor milyen lehetőségeik vannak, kihez, hova lehet fordulni. A kényszermunka ügyek során egy másik módszer is körvonalazódott, amikor az elkövető költözik be a sértetthez. Az elkövetö albérlőként, eleinte segítőként költözik a sértett ingatlanába, 
ahol lassan átveszi az uralmat a jellemzően egyedülálló, idős sértett fölött. Ez kevésbé hosszú ideig tartó elkövetés volt, ezekben az ügyekben a sértettek sokkal inkább mertek a rendőrséghez fordulni segítségért, hiszen a saját tulajdonú ingatlanukban történt a jogsértés. „A 25 éves sértett férfi két hónap után tett a rendörségen feljelentést: nevelöszülöknél nevelkedett sértettnek a gyámhivatal vásárolt egy ingatlant, ahol 3 évig egyedül élt. Nehezen tartotta el magát, igy albérlöket keresett, ezt követöen beköltözött hozzá a gyanúsitott a feleségével és 6 gyermekével. Onnantól ő kiszorult a házból, csicskáztatták, bántalmazták, a gyermekek és az , albérlök” ellátására, favágásra kötelezték." (Eset5) (Hercsel, 2018.) „A sértett ellátásáért lakóingatlanába fogadta a két vádlottat, ápolásért cserébe a nevén lévö ingatlant és ingóságait gondozás fejében vádlottakra hagyja halálozását követöen. De a vádlottak nem adtak enni a sértettnek, inzulint sem vettek neki, a sértett jelentette a rendörségnek, mert nagyon leromlott az egészségügyi állapota; a második sértettet a nénihez beköltöztették, és különbözö büncselekmények elkövetésére utasitották (pl. gyümölcsfákat vágtak ki, kályhát, hütöt loptak, betöréses lopások)." (Eset6) (Hercsel, 2018.) A szexuális célú kizsákmányolás jellemzően a prostitúciós tevékenységre kényszerítésben nyilvánult meg. Mind az utcai, mind a lakásban végzett szexuális szolgáltatások jelen voltak, az interneten elérhetők mellett. A sértettek ezekben az ügyekben sokszor zürös családi háttérrel rendelkező, jellemzően fiatal lányok és nők, akik könnyedén megvezethetők, kihasználhatók voltak.

\section{Hasonlóságok az emberkereskedelem és a családon belüli erőszak között}

A családon belüli erőszakkal a hazai szakirodalomban is számos tanulmány, kutatás foglalkozik, azonban empirikus kutatás a jelenség széleskörü, komplex feltárására kevés vállalkozik (a gyermekbántalmazásról, a kiskorú veszélyeztetéséről, a kapcsolati erőszakról, azaz az igen fontos részjelenségeiről viszont igen), ugyanakkor a tragédiába torkolló esetek miatt - az emberkereskedelemhez hasonlóan - a média által felkapott téma (Virág et al., 579-582.). A 2005-ben megjelent „Családi iszonyok” címü kötetben már erről ír Szöllősi Gábor: mit jelent a családon belüli erőszak kifejezés, ki és hogyan érti (néha félre), „nem jogszabály határozza meg a diskurzus tartalmát, hanem a diskurzus résztvevöi törekednek álláspontjuk jogszabályi formában történö megjelenitésére" (Szöllősi, 2005, 67.). Időközben a 2012. évi C. törvényben (212/A. §) a kapcsolati erőszak szubszidiárius tényállásként az anyagi jog része lett, de a két jelenség összetettsége és a kriminológiai jellemzőik bemutatása miatt, mégis a családon 
belüli erőszak kifejezést használjuk, abban az értelemben, ahogy azt az OKRI egy korábbi kutatásában alkalmaztuk ${ }^{4}$ : ,az együtt élö és egymással fizikai, érzelmi, anyagi, jogi függésben lévő személyek között megvalósuló eröszak, bántalmazás, visszaélés, amely magában foglalja a fizikai, szexuális, érzelmi bántalmazás vagy elhanyagolás valamennyi formáját." (Virág, 2005) Sem a családon belüli erőszakról, sem az emberkereskedelemről nem tudunk valós képet rajzolni a kriminálstatisztikai adatok alapján. Mindkét jelenség esetében kijelenthető, hogy igen magas a látencia, az emberkereskedelem esetében különösen alacsony az ügyek száma (például 2016-ban az ENYÜBS - Egységes nyomozó hatósági és ügyészségi bünügyi statisztika - adatai alapján nulla regisztrált emberkereskedelmes ügy volt). Bár itt a jelenségről, annak kriminológiai jellemzőiről szólunk, mégis érintőlegesen említést kell tennünk az esetek minősítési kérdéseiről is. A kriminálstatisztika csak azokat az ügyeket jelzi kapcsolati erőszaknak, emberkereskedelemnek vagy éppen kényszermunkának, ahol ez a minősítés jelenik meg. Ugyanakkor a 2012. évi C. törvény 2013. július elsejei hatályba lépését követően a jogalkalmazói gyakorlatot vizsgálva, kijelenthető ,a rendörségek a kapcsolati eröszak büncselekményét és az esetleges halmazatokat (tipikusan kiskorú veszélyeztetés, magánlaksértés...) - kevés kivételtöl eltekintve - egyáltalán nem ismerikfel még úgy/akkor sem, hogy annak tényállási elemeit maguk rögzitik a kezdö iratokon, összefoglaló jelentésekben, elöterjesztésekben, egyéb iratokon." (Garai, 2019, 38.) Ezt az emberkereskedelem esetén is elmondhatjuk (nyilvánvalóan más halmazati büncselekményekkel). A Btk. 192. §-ának helyes alkalmazását segítendő 2018 októberében a Legfőbb Ügyészség kiadta a KSB 3771/2018/5-I- NF. 3889/2014/11. számú iránymutatását, amelyben az emberkereskedelem esetében a kizsákmányolás és a kiszolgáltatott helyzet értelmezése, a kerítés büncselekményétől való elhatárolását foglalja magában, amely ennek a gyakorlatnak a megváltoztatását tüzte ki célul, és várhatóan a statisztikai adatokban ez kimutathatóan meg is történik. Az emberkereskedelemmel kapcsolatban a családon belüli erőszak vagy a gyermekek bántalmazása során felmerülő hatalmi helyzet szintén fennáll és az elkövetők rendkívül hasonló eszközrendszert alkalmaznak. Úgy gondolják, hogy bármit megtehetnek a kiszolgáltatott sértettel (véleményem szerint éppen ez az, amit üzenetértékü ítéletekkel lehetne korlátozni). Az emberkereskedelemmel kapcsolatos ügyekben éppen ennek a kiszolgáltatott helyzetnek az értelmezése - annak erősen szubjektív megítélése miatt - rendkívül nehéz a jogalkalmazók számára. Az emberkereskedelem esetén csakúgy, mint a családon belüli erőszaknál, a sértett anyagi függőségben él az elkövetővel szemben. Az emberkereskedelmes

4 Jelen sorok írója is részt vett a vizsgálatban. 
ügyekben a rossz anyagi helyzetben lévő sértettek kihasználása, megvezetése, függővé tétele az egyik fontos lépés. Az anyagi függőségben élő sértett ebből a helyzetből történő kilépése a kilátástalanságba még kevésbé valószínű. Az agresszió jelenségéről, fogalmáról és elméleteiről Hárdi István szerkesztett egy tanulmánykötetet, amelyben jelzi, hogy a „trágár szavak korszakát éljük”. Ezzel együtt a fizikai agresszió megszokottá válásával is szembesülnünk kell (Hárdi, 2010, 34.; Virág et. el., 2016). A mindennapi, de főleg az úgynevezett rosszindulatú agresszió egyre gyakoribbá válása szintén tetten érhető volt az általunk vizsgált iratokban (Hárdi, 2010, 56.). A fizikai abúzus, az agresszió szinte minden emberkereskedelmes ügyben előfordult. Mind a verbális, mind a testi eröszak jelen volt az esetek többségében. A Btk. 459. § 4. záró rendelkezése alapján „eröszakos magatartásnak minösül a más személyre gyakorolt támadó jellegü fizikai ráhatás is, abban az esetben is, ha az nem alkalmas testi sérülés okozására, valamint a fenyegetés súlyos hátrány kilátásba helyezése, amely alkalmas arra, hogy a megfenyegetettben komoly félelmet keltsen." A kényszermunka ügyekben sokszor ez utóbbi önmagában is elérte a kívánt hatást. „Gyakoribb ott az agresszió, ahol ez elfogadott közösségi norma. Mindez a társadalmi tényezök fontosságára utal. Természetesen számos más szociális tényezö is lehet az agresszió hátterében: a szegénység, a munkanélküliség, a hajléktalanság, a menekültek és a kisebbségek nehéz helyzete, a társadalom peremére kerülés." (Hárdi, 2010, 84.) Ez utóbbiak szinte minden általunk vizsgált esetben világosan felszínre kerültek. A családon belüli erőszak esetében a fizikai bántalmazás eszkalálódása, az egyre erősebbé válása a ciklikus erőszak modellnek megfelelöen zajlik (Virág et. al., 2016, 581.), csakúgy, mint az emberkereskedelmes ügyek során. A fizikai mellett a pszichikai bántalmazás jelenléte is minden esetben fellelhetô, úgymint a megfélemlítés, a folytonos lebecsülés, megalázás, szégyenérzet keltése, fenntartása (lásd a bevezetőben idézett vallomást). A szexuális bántalmazás a szexuális célú kizsákmányolás esetében szintén igen elterjedt. A szexuális kizsákmányolás során az egyik legjellemzőbb elkövetési mód az úgynevezett loverboys metódus, azaz a szerelmi kapcsolatra épülő játszma: az érzelmi függésben lévő, jellemzően nő sértettet a férfi, szerelmükre hivatkozva veszi rá a prostitúciós tevékenységre, akit rendszerint fizikailag is bántalmaz, ha ezt mégsem akarja megtenni. „A sértett szerelmi viszonyt kezdeményez a vádlottal. Két hetes együttélést követöen a vádlott elmondja a sértettnek, hogy prostituáltak futtatásával foglalkozik, a barátnöje éppen Ausztriában dolgozik és az ö számára hazaküldött pénzéböl tartja fent magát. A vádlott felveti, hogy a sértett is dolgozhatna neki, majd a keresményen fele-fele osztoznának. A sértett beleegyezik ebbe: P-ról Gy-be mennek, ahol egy éjszaka 4-5 kuncsaftot fogad, amellyel 80 ezer Ft-ot keres, ám abból végül csak 10 ezret kap vissza. 
A Bécsben dolgozó barátnö ennek az új kapcsolatnak nem örült, így a vádlott eladta a sértettet a 2. és 3. rendü vádlottaknak 10 ezer Ft-ért. A sértett tette meg a feljelentést ezt követöen. Saját vallomása szerint ,, kalandvágyból fogadta el elsö rendü vádlott segitségét abban, hogy ismerösénél segit helyet keresni neki, mert hazatérni a szüleihez semmiképpen nem akart." (Eset7). (Hercsel, 2018) Kiemelendő: szexuális abúzus munkacélú kizsákmányolások során, az általunk vizsgált ügyekben, nem fordult elö. A fizikai korlátok, határok megszabása, az iratok elvétele, a pénztelenség, a külső kapcsolatok tartása ugyanakkor az emberkereskedelmes ügyek mindegyikében szerepet kapott. Ez volt a legérdekesebb, legvitatottabb kérdés: ha valaki szabadon mozoghat, miért nem ment el, hagyta ott az elkövetőt. Számításba ritkán vették, hogy sem irata, sem pénze, sem lehetösége nem volt elhagyni az elkövetőt.

\section{Különbségek}

A két jelenség közötti különbségek bemutatása is elengedhetetlen. Az emberkereskedelmes ügyekben ritka volt az, amikor csak egy sértett volt, jellemző a több sértett sérelmére történő elkövetés, és a családon belüli erőszakhoz képest sokkal nehezebb ennek megállapítása. Az emberkereskedelem áldozatát - a családon belüli erőszakéval ellentétben - külön jogszabály alapján azonosítják, rá speciális szabályok vonatkoznak a nemzetközi elvárásoknak, uniós irányelvnek köszönhetően. A hazai jogszabályokban expressis verbis megjelenik az emberkereskedelem áldozata fogalom is. Szót kell ejteni a 354/2012. (XII. 13.) kormányrendelet az emberkereskedelem áldozatai azonosításának rendjéről címü dokumentumról, amely meghatározza az azonosításban részt vevő szerveket, és mellékletként egy kitöltendő azonosító adatlapot csatol, amely az áldozattá válásra utaló jeleket is tartalmazza. Az azonosításban való részvételhez a potenciális áldozatnak hozzájáruló nyilatkozatot kell aláírnia. ,Amennyiben az azonositást végzö szerv hatáskörébe tartozó eljárása során vagy egyébként olyan magyar állampolgárra, vagy a szabad mozgás és tartózkodás jogával rendelkezö személyre vonatkozóan, akiröl alappal feltehetö, hogy az emberkereskedelem áldozata, ezen helyzetröl hivatalos tudomást szerez vagy azt egyébként észleli, vele azonositó beszélgetést folytat le." Ez a kormányrendelet nagy, illetve közepes valószínűségre utaló jeleket határoz meg: a sértett megjelenésére, személyes, valamint munkakörülményeire, tevékenységvégzésének körülményeire vonatkozóan. Ezen indikátorok ismerete elengedhetetlen az emberkereskedelem áldozatainak felismerésekor. A 2005. évi CXXXV. törvény (Ástv.) 4. $\S$ (6) alapján az állam az emberkereskedelem áldozataként azonosított, magyar 
állampolgárságú vagy a szabad mozgás és tartózkodás jogával rendelkező személy számára, tekintet nélkül arra, hogy az 1. § (1) bekezdésében és a 2. §-ban meghatározott büncselekmény miatt büntetőeljárás indult-e, szükség szerint védett szálláshelyet biztosít. Védett szálláshely az emberkereskedelem áldozataként azonosított személyt befogadó és számára jogszabályban meghatározott ellátásokat nyújtó létesítmény. A bünügyi nyomozással és büntetőeljárással való együttmüködésükhöz kötődő védelem. Az emberkereskedelem esetében a különböző célú kizsákmányolási formák nem szerinti specializáltsága triviális a téma ismerői számára. Az emberkereskedelem áldozatai között, különösen a munkacélú kizsákmányolás esetén a férfi sértettek száma jelentős. Míg a családon belüli erőszak esetében a férfi sértettekről sajnálatosan kevés szó esik (Tamási, 2005). Ugyanakkor az emberkereskedelem férfi áldozatai részére is rendelkezésre állnak erőforrások az ő speciális igényeinek kielégítésére (URL3). Az emberkereskedelmes ügyekben az alkohol- és a kábítószer-használat a sértettek esetében gyakran fordult elö, a prostitúciós tevékenységre kényszerítettek csupán ezek (leginkább drogok) segítségével tudták a megfelelő számú klienst kiszolgálni, az elöírt napi keresetet előteremteni. A családon belüli erőszak jelenségekor a magyar társadalom általános, súlyos alkoholproblémái köszönnek vissza, mind a sértetti, mind az elkövetöi oldalon (Windt, 2005, 170.). Az egyik legmarkánsabb különbség a családon belüli erőszak és az emberkereskedelem között, hogy az utóbbit nemcsak országon belül, hanem országhatárokon átívelő módon, más országokban is meg lehet valósítani. A nemzetközi emberkereskedelem a szervezett bünözés egyik legnagyobb profitot termelő ágazata. A határon átnyúló jelleg az emberkereskedelmi kutatások során mindig is elsődleges volt, az általunk 2019-ben lefolytatott vizsgálatban azonban éppen a határokon belüli esetek domináltak.

\section{Befejezés}

Mind az emberkereskedelem, mind a családon belüli erőszak esetében elmondható, hogy a sértett sok esetben nem érzi áldozatnak magát, az elkövető hoszszú ideig tulajdonaként kezeli a sértettet, akként is bánik vele, sárba tiporja. Az elkövetők elhitetik a sértettjeikkel, hogy ők semmit sem érnek, nélkülük nem képesek semmire, úgyis megtalálják őket, hiszen van ismerősük mindenhol. Éppen ezért mindkét jelenség esetében rendkívül fontos a társadalmi tudatosság növelése, hogy a környezet is felismerje az eseteket, merjenek és tudjanak is jelezni a hatóságoknak. Ugyanakkor a sértettek részére is szükséges figyelemfelkeltő kampányok során elmondani, hangsúlyozni, hogy az Országos 
Kríziskezelő és Információs Telefonszolgálat (OKIT) munkatársai a bántalmazottak segélyvonalán elérhetők (URL3). A másodlagos viktimizáció megelőzése mindkét jelenség esetében különösen fontos, a már segítséget kérök, illetve az eljárásban részt vevő sértettek szinte mindegyike különleges bánásmódot igényel, ezért az igazságszolgáltatás szereplöinek is figyelembe kell ezt venniük. Az emberkereskedelmes esetekben a sértett és az elkövetö között nem feltétlenül áll fenn családi kapcsolat, de a hatalmi fölény megléte, a sértett kiszolgáltatottságának megteremtése vagy annak erősítése mindenképpen meghúzódik a háttérben, ennek ismerete és felismerése a nyomozó hatóságok részéről mindenképpen szükségszerü ahhoz, hogy megfelelő módon tárja fel, minősítse a tudomására jutott esetet.

\section{Felhasznált irodalom}

Betlen A. (2013): Legfőbb érték az ember... azazhogy a nő. Nőelszívás: a prostitúció a gazdaságban. Társadalmi Nemek Tudománya, 3(1), 95-112.

Doyle, D. M., Murphy, C., Murphy, M., Coppari, P. R. \& Wechsler, R. J. (2019): 'I Felt Like She Owns Me': Exploitation and Uncertainty in the Lives of Labour Trafficking Victims in Ireland. The British Journal of Criminology, 59(1), 231-251. https://doi.org/10.1093/bjc/azy025

Fehér L. (2005): Illegális migráció, embercsempészet, emberkereskedelem. In Irk F. (szerk.): Kriminológiai Tanulmányok, 44. Országos Kriminológiai Intézet, 210-233.

Fehér L. (2012): Az emberkereskedelem komplex problémája. Állam- és Jogtudomány, 53(4), $397-420$.

Forrai J. (2009): Szex, prostitúció, erőszak. Semmelweis Kiadó

Garai R. (2019): A kapcsolati erőszak büncselekményének jogalkalmazási gyakorlata - a jogerős ítéletek tanulságai. In Vókó Gy. (szerk.): Kriminológiai Tanulmányok, 56. Országos Kriminológiai Intézet, 30-47.

Garai R. (2017): A kapcsolati erőszak dilemmái. Tények és tévhitek a gyakorlatban. In: Vókó Gy. (szerk.): Kriminológiai Tanulmányok 54. Országos Kriminológiai Intézet, 181-196.

Hárdi I. (2010): Az agresszió világa. Medicina Könyvkiadó Zrt.

Hercsel A. (2018): Láthatatlan pokol: túléléstörténetek a családon belüli eröszak höseiröl. Partvonal

Kránitz M. (2013): Prostitúció fiatal korban - tinédzser prostituáltak. In: Vókó Gy. \& Tamási E. (szerk.): Kriminológiai Tanulmányok 50. Országos Kriminológiai Intézet, 65-104.

Mihalkó V., Nagy B. \& Szabó M. (2017): Az emberiség tragédiája, Modernkori rabszolgaság. Anthropolis Egyesület

Póczik Sz. \& Dunavölgyi Sz. (szerk.) (2008): Nemzetközi migráció - nemzetközi kockázatok. HVG Orac 
Segrave, M., Hedwards, B. \& Tyas, D. (2020): Family violence and Exploitation: Examining the Contours of Violence and Exploitation. In Winterdyk, J. \& Jones, J. (szerk.): The Palgrave International Handbook of Human Trafficking, Palgrave Macmillan, 437-450. https://doi. org/10.1007/978-3-319-63058-8_24

Solt Á. (2009): Az emberkereskedelem áldozatait segítő intézményrendszer működési jellemzői - egy kvalitatív kutatás eredményei. In Gyurkó Sz. \& Virág Gy. (szerk.): Emberpiac. A Magyarországot érintő nemzetközi emberkereskedelem társadalmi, kriminológiai jellemzöi. Eszter könyvek, 30-56.

Tamási E. (2005): A férfiak sérelmére elkövetett családon belüli erőszak. In Virág Gy. (szerk.): Családi iszonyok. A családi eröszak kriminológiai vizsgálata. KJK-Kerszöv, 192-219.

Virág Gy., Kulcsár G. \& Rosta A. (2016): Erőszakos bünözés. In Borbíró A., Gönczöl K., Kerezsi K. \& Lévay M.: Kriminológia. Walters Kluwer Kft, 553-602.

Windt Sz. (2019): Az emberkereskedelmi ügyek sajátosságai, a kizsákmányolás kriminológiai és szociológiai értékelése. Kutatási jelentés. Országos Kriminológiai Intézet

Windt Sz. (2019): Gondolatok az emberkereskedelemről. Miskolci Jogi Szemle, 14(2), 459-469.

Windt Sz. (2005): Összefoglaló az empirikus vizsgálatról. In Virág Gy. (szerk.): Családi iszonyok. A családi erőszak kriminológiai vizsgálata. KJK-Kerszöv, 153-170.

\section{A cikkben található online hivatkozások}

URL1: Data collection on trafficking 2018 in human beings in the EU. https://ec.europa.eu/home-affairs/sites/homeaffairs/files/what-we-do/policies/european-agenda-security/20181204 data-collection-study.pdf

URL2: European Union Serious and Organised Crime Threat Assessment 2017. https://www. europol.europa.eu/activities-services/main-reports/european-union-serious-and-organised-crime-threat-assessment-2017

URL3: Országos Kriziskezelő és Információs Telefonszolgálat. http://bantalmazas.hu/ 